\title{
GAYA BAHASA K.H. ZAINUDDIN M.Z. DALAM CERAMAH ISRA MIKRAJ DI TANGERANG SELATAN
}

\author{
Eka Anjani \\ STID Al-Hadid, Surabaya \\ khaylillakamelia@gmail.com
}

\begin{abstract}
Abstrak: Studi gaya bahasa dikaji karena dalam menyampaikan ceramah seorang dai harus bisa membuat pesannya dipahami sekaligus menarik untuk didengarkan. Salah satu cara yang bisa dilakukan oleh penceramah adalah dengan menggunakan gaya bahasa. Gaya bahasa berfungsi untuk menciptakan pemahaman yang selaras antara hadirin dengan penceramah. K.H. Zainuddin M.Z. adalah salah seorang kiai yang mampu menyampaikan gaya bahasa dengan tepat dan selaras. Tujuan studi ini adalah untuk mendeskripsikan penggunaan gaya bahasa yang disampaikan K.H. Zainuddin M.Z. pada struktur pembuka, isi, dan penutup pesan. Adanya studi ini diharapkan bisa menjadi pembelajaran bagi dai baru dalam menentukan gaya bahasa agar lebih menarik perhatian para pendengar. Studi ini menggunakan metode kualitatif deskriptif. Hasil studi ini didapatkan bahwa K.H. Zainuddin M.Z. dalam pembuka ceramah menggunakan gaya bahasa oksimoron untuk membangun krediblitas dan litotes untuk membangun rasa penasaran. Pada isi ceramah beliau menggunakan gaya bahasa yang lebih variatif seperti ellipsis, koreksio, metonimia, sedangkan untuk memperindah pesan menggunakan asonansi, apostrof, dan aliterasi. Pada penutup ceramah, digunakan gaya bahasa asonansi dan hiperbola untuk memberikan keindahan dan penekanan kesimpulan.
\end{abstract}

Kata kunci: gaya bahasa, ceramah, K.H. Zainuddin M.Z.

The Figure of Speech in K.H. Zainuddin M.Z.'S Sermon of Isra Mikraj. Abstract: Study on Figure of speech is conducted in order that a da'i (proselytizer), in his sermon, must be able to make his messages understandable and at the same time interesting to listen. One way which a proselytizer can do about is by using figure of speech. Figure of speech functions to create harmonious understanding between audience and proselytizer. K.H. Zainuddin M.Z. is one of kiai/proselytizers who is able to convey appropriate and harmonious figure of speech. This study aims to describe the usage of figure of speech conveyed by K.H. Zainuddin M.Z. in the structure of opening, content, and ending of the message. This study existence is hoped to be a learning media for new dai/proselytizers to determine certain figures of speech in order to be more interesting for audience. This study uses descriptive qualitative method. This study results that KH Zainuddin M.Z. uses oxymoron to build the credibility and litotes to build the audience curiosity in the opening of sermon. In the content of sermon, he uses more varied figures of speech such as elliptical style, epanorthosis, metonymy and beautifies the message by using assonance, apostrophe and alliteration. He uses assonance and hyperbole to emphasize and beautifies the message in the end of sermon.

Keywords: figure of speech, sermon, K.H. Zainuddin M.Z. 


\section{Pendahuluan}

Salah satu metode dakwah yang umum dilakukan oleh umat Islam untuk mendakwahkan ajarannya adalah dakwah bil lisan. Akan tetapi, tidak semua orang mampu melakukan dakwah bil lisan. Hal ini dikarenakan, dakwah dilakukan secara langsung. Setiap kata perkata yang diucapkan oleh mubalig, bisa langsung direspons oleh mad'uw. Selain itu mubalig juga harus tetap mempertahankan minat mad'uw untuk tetap tertarik mendengarkan. Agar bisa sukses melakukan dakwah bil lisan, mubalig harus benar-benar mempersiapkan pesan dakwah dengan matang. Menurut Ali Aziz dalam bukunya ilmu pidato yang dikutip dari skripsi Siti Nur Sofiyatin menyebutkan bahwa sukses atau tidaknya pidato yang bisa meyakinkan dan menggerakkan mad'uw untuk bertindak, bergantung pada persiapan-persiapan yang dilakukan sebelumnya. ${ }^{1}$ Persiapan-persiapan tersebut salah satunya adalah penyusunan pesan yang di dalamnya terdapat penggunaan gaya bahasa. ${ }^{2}$

Gaya bahasa yang dipilih akan membentuk corak yang akan menjadi ciri khas dari pendakwah. Oleh karena itu, selain menghayati isi yang harus dikemukakan, pendakwah juga harus peka terhadap gaya bahasa yang dipilihnya. Gaya bahasa seseorang baik secara lisan mupun tulisan

\footnotetext{
1 Nayla Zamzamy, "Teknik Pesiapan Dakwah Siti Maisaroh" (Skripsi, Universitas Islam Negeri Sunan Ampel Surabaya, 2018), 6

2 Jalaluddin Rakhmat, Retorika Modern Pendekatan Praktis (Bandung: Remaja Rosdakarya, 1992), 50.

3 Maya Gustina Sucipto, Ensiklopedia Bahasa dan Sastra Indonesia Gaya Bahasa, (Klaten: Intan Pariwara, 2018), 1.

4 Rakhmat, Retorika Modern., 50.
}

dapat menimbulkan reaksi mad'uw berupa tanggapan, ${ }^{3}$ menimbulkan kesan yang kuat, hidup, dan merebut perhatian mad'uw. ${ }^{4}$ Gaya bahasa memanfaatkan bahasa kias (bahasa figuratif). Bahasa kias dipakai untuk mengungkapkan sesuatu dengan tidak menunjuk secara langsung objek yang dituju. Penggunaan bahasa kias dimaksudkan untuk menunjukkan efek tertentu. Efek tersebut membuat isi yang dikemukakan lebih menarik dan menimbulkan keindahan bahasa. Bahasa kias bisa digunakan untuk membangkitkan suasana dan kesan tertentu, tanggapan indera, memperindah penuturuan, menimbulkan kesegaran, dan terutama menimbulkan kejelasan gambaran angan. ${ }^{5}$ Sebaliknya, penggunaan tidak tepat gaya bahasa akan sia-sia belaka, bahkan mengganggu pembaca atau pendengar. ${ }^{6}$

Dalam penyampaian pesan kepada mad'uw, pendakwah memiliki kekhasan. Salah satunya adalah dalam hal bahasa. Ustaz K.H. Zainuddin M.Z. adalah ustaz yang dikenal dengan tata bahasa yang teratur, bermain logika, dan retorika, humor yang mengena, intonasi suara yang khas, komunikatif dengan jemaah sehingga ia pun mendapatkan julukan Dai Sejuta Umat. ${ }^{7}$ K.H. Zainuddin M.Z. adalah pendakwah yang sangat sering diminta untuk mengisi ceramah baik itu off air maupun on air. Beliau pernah dikontrak oleh sebuah biro perjalanan haji yang

\footnotetext{
5 Maya Agustina S, Gaya Bahasa Pengetahuan dan Penerapan (Klaten: Intan pariwara, 2018), iii 6 Ibid.

7 Bangkatimes.com, "Hadir di Pangkalpinang, Ustaz H M Syauqi MZ Obati Kerinduan Umat Kepada KH Zainuddin MZ," Bangkatimes.com, 23 Juli 2017, http://bangkatimes.com/23/07/2017/hadir-dipangkalpinang-ustaz-h-m-syauqi-mz-obatikerinduan-umat-kepada-kh-zainuddin-mz/.
} 
bekerjasama dengan televisi swasta, bersafari bersama artis ke berbagai daerah yang disebut "Nada dan Dakwah". Beliau juga mendapatkan gelar doktor honoris causa dari Universitas Kebangsaan Malaysia. K.H. Zainuddin M.Z. yang lahir 2 Maret 1952 di Jakarta ini tentunya memiliki daya tarik tersendiri dalam menyampaikan ceramah. Daya tarik tersebut tecermin dalam pemilihan gaya bahasa erotesis dengan menggunakan kata "betul?". Gaya tersebut pernah ditiru pelawak yang kini jadi pendakwah juga, Kiwil. Karena kekhasan yang dimiliki, kiai lulusan S-1 IAIN Syarif Hidayatullah tersebut ceramahnya amat dinantikan umat muslim masa itu. Selain karena materi yang sederhana, juga karena gaya berceramahnya yang tak jarang mengundang tawa. ${ }^{8}$

Ceramah K.H. Zainuddin M.Z. yang diangkat dalam studi ini adalah ceramah yang dilakukan di kampung Dongkal, Serpong, Tangerang Selatan untuk memperingati Isra Mikraj pada tahun 2011. Ceramah ini terasa istimewa karena dihadiri oleh Sekretaris Daerah dan diliput oleh televisi lokal. Ceramah yang mengangkat tema "Membangkitkan Semangat Keimanan Dan Rasa Ukhuwah Islamiah Sesama Muslim" ini juga diunggah ulang di media youtube oleh tiga akun, yakni akun bang mu2 official; Ceramah

8 Petrik Matanasi, "Zainuddin MZ: Dai Sejuta Umat, Politikus Sejuta Massa," tirto.id, 5 Juli 2011, https://tirto.id/zainuddin-mz-dai-sejuta-umatpolitikus-sejuta-massa-cCKz.

9 Link youtube antara lain: Bangmu2 Official, ceramah KH Zainuddin MZ lucu,, "Isro Mikroj", MP4 Video, 00.00-01.10.05 (Dongkal, Serpong, Tanggerang Selatan, 2018), https://www.youtube.com/watch?v=CULilzpoxN8\& $\mathrm{t}=15 \mathrm{~s}$; CERAMAH KH ZAINUDDIN MZ, Waduh $\mathrm{lbu}-\mathrm{lbu}$
K.H. Zainuddin M.Z.; dan K.H. Zainuddin M.Z. - Memories. 9 Berdasarkan pengamatan penulis saat mendengarkan ceramah K.H. Zainuddin M.Z. ini, mad'uw terlihat sangat tertarik dengan ceramah tersebut. Hal ini dilihat dari respon mad'uw ketika K.H. Zainuddin M.Z. bertanya tentang batas waktu ceramah "sampai jam berapa ini?" mad'uw kemudian menjawab "sampai jam satu", Maksudnya adalah sampai jam satu malam, ini menunjukkan mad'uw ingin mendengarkan ceramah lebih lama dari jadwal yang telah ditentukan. Selain itu, ketika ceramahnya diunggah di akun "Ceramah K.H. Zainuddin M.Z." mendapatkan respon yang bagus dari masyarakat yang menonton.

Respon mad'uw ketika ditanya oleh K.H. Zainuddin M.Z.. "Marah nggak?," mereka semua menjawab dengan kompak "marah". Ketika diberikan humor oleh K.H. Zainuddin M.Z. mereka tertawa, seperti, "Hoey, kita kudu jaga gawang. bu, jaga gawang. bu, gawang ibu jaga." Diajak menyanyikan Tuhan Saya Satu dengan nada lagu Topi Saya Bundar, juga diikuti secara kompak oleh mad'uw. Hal ini menunjukkan bahwa K.H. Zainuddin M.Z. mampu menyampaikan pesan dengan baik, gaya bahasa yang dipilih juga mampu membuat kesegaran terhadap hadirin terhadap ceramah yang diberikan. Ini

Ketawa Terpingkal-pingkal Ngakak-Live $\mathrm{KH}$. Zainuddin MZ, MP4 Video, 00.00-01.09.45 (Dongkal, Serpong, Tanggerang Selatan, 2018); https://www.youtube.com/watch?v=mftrf40MoOI \&t=21s.;KH ZAINUDDIN MZ - MEMORIES, CERAMAH TERAKHIR SEMINGGU SEBELUM MENINGGAL KH ZAINUDDIN MZ PART 1, MP4 Video, 00.00-14.49 (Dongkal, Serpong, Tanggerang Selatan, 2018), https://www.youtube.com/watch?v=Nw1hadoo6A c. 
menunjukkan respons yang disampaikan oleh K.H. Zainuddin sesuai dengan yang diharapkan dan menunjukkan keberhasilan penggunaan gaya bahasa yang digunakan oleh K.H. Zainuddin M.Z. dalam ceramahnya.

Studi sebelumnya tentang gaya bahasa di antaranya adalah "Studi Diksi dan Gaya Bahasa pada Pesan Dakwah Kiai Syafiul Anam dalam Acara Silaturrahim tanggal 17 Juni 2018 di Desa Penidon, Plumpang, Tuban," studi yang digunakan menggunakan metode deskriptif kualitatif. 10 Studi lainnya adalah "Analisis Diksi dan Gaya Bahasa Ceramah Ustaz Abdul Shomad di Masjid Al-Jihad Medan," studi ini dilakukan oleh Viviana Pratiwi Andriani. ${ }^{11}$ Studi tentang gaya bahasa juga dilakukan oleh Wisnu Ardana A. Jiarianto dengan judul "Kajian Diksi dan Gaya Bahasa Ceramah Agama K.H. Abdullah Gymnastiar."12 Berdasarkan data tersebut masih belum ada studi gaya bahasa yang disampaikan oleh K.H. Zainuddin M.Z.. Selain itu studi yang dilakukan penulis tidak hanya mengidentifikasi gaya bahasa saja akan tetapi dihubungkan dengan fungsi gaya bahasa terhadap orientasi per masing-masing bagian ceramah mulai dari bagian pembuka pesan, isi pesan dan penutup pesan. Sedangkan penelitian diksi tidak dijadikan fokus penelitian karena dalam analisis pilihan diksi hanya mengidentifikasi ragam diksi yang

10 Mohammad Niamulloh, "Diksi Pesan Dakwah Kiai Syafi'ul Anam dalam Acara Silaturrahim Tanggal 17 Juni 2018 di Desa Penidon-Plumpang-Tuban" (Skripsi, UIN sunan Ampel Surabaya 2018), vi.

11 Viviana Pratiwi Andriani, "Analisis Diksi dan Gaya Bahasa Ceramah Ust. Abdul Somad di Masjid AlJihad Medan" (Skripsi, Universitas Muhammadiyah Sumatera Utara, Medan), Abstrak digunakan seperti ragam diksi ilmiah, jargon, konotasi, denotasi, populer, dan percakapan sedangkan fungsi pemilihan diksi dalam komunikasi tidak menjadi fokus analisis.

Tulisan ini bertujuan untuk mendeskripsikan penggunaan gaya bahasa K.H. Zainuddin M.Z. saat peringatan Isra Mikraj di kampung Dongkal, Serpong, Tangerang Selatan Tahun 2011. Fokusnya adalah analisis penggunaan gaya bahasa berdasarkan langsung tidaknya makna dalam penyampaian pesan dakwah sehingga mampu menarik minat mad'uw.

Metodologi studi ini adalah kualitatif deskriptif, ${ }^{13}$ hal ini dikarenakan tujuannya mendeskripsikan secara mendalam tentang penggunaan gaya bahasa yang digunakan K.H. Zainuddin M.Z. pada ceramah di Dongkal Tangerang Selatan pada tahun 2011. Ceramah tersebut berisi tiga topik besar yakni topik tentang "Isra Mikraj meningkatkan iman, menjaga ukhuwah serta meningkatkan ibadah kepada Allah SWT." Akan tetapi yang menjadi objek pengamatan adalah topik pertama, hal ini dikarenakan topik tersebut menjadi tema utama dan menjadi topik yang paling lama dibahas dalam ceramah tersebut yakni kurang lebih 30 menit. Sumber data yang digunakan adalah file video ceramah yang didapatkan dari akun youtube "Ceramah

12 Wisnu Ardana A.Jiarianto, "Kajian Diksi dan Gaya Bahasa Ceramah Agama KH. Abdullah Gymnastiar." (Skripsi, Universitas Airlangga Surabaya, 2016) diakses $\quad 27 \quad$ April 2019 http://repository.unair.ac.id/48656/

13 John W. Creswell, Research Design Pendekatan Kualitatif, Kuantitatif, dan Mixed, diterjemahkan oleh Achmad Fawaid (Yogyakarta: Pustaka Pelajar, 2014), 276. 
Zainuddin M.Z.". Dalam penyampaian, ceramah K.H. Zainuddin M.Z. terdiri dari tiga struktur yakni pembuka, isi, dan penutup. Sedangkan pada inti pesan, terdiri dari tiga hal yakni Isra Mikraj adalah peristiwa iman; menjaga kesatuan, persatuan, kerukunan; dan meningkatkan ibadah kepada Allah SWT. Pada studi ini akan dianalisis pembukaan yang dimulai pada 00.12-02.35, sedangkan untuk isi pesan hanya menyampaikan satu topik saja yakni Isra Mikraj adalah peristiwa iman karena isi pesan ini sesuai dengan tema acara yang diselenggarakan serta pembahasannya menghabiskan waktu paling banyak dibandingkan dengan inti pesan yang lain yakni pada 02.35-32.02 sedangkan bagian penutup pada menit ke 56.25-01.09.43. Teknis analisis yang digunakan adalah reduksi data, klasifikasi data, dan analisis gaya bahasa.

\section{Konsepsi Ceramah}

Metode ceramah atau muhadlarah atau pidato ini merupakan salah satu metode dakwah yang dilakukan dengan komunikasi searah di hadapan publik, atau biasa dikatakan public speaking. Meskipun lebih banyak satu arah, komunikasi ceramah sering juga diselingi atau diakhiri dengan komunikasi dua arah (dialog) dalam bentuk tanya jawab. Pesan yang disampaikan juga bersifat ringan, informatif, dan tidak mengundang perdebatan. Dialog yang dilakukan juga terbatas pada pertanyaan, bukan sanggahan. ${ }^{14}$

\footnotetext{
14 Ali Aziz, Ilmu Dakwah Edisi Revisi (Surabaya: Prenada Media Group, 2016), 359.

15 Ibid., 365.

16 Rakhmat, Retorika Modern., 53.
}

Susunan ceramah terdiri atas tiga hal yakni pembukaan, isi, dan penutup. Ali Aziz menyatakan dalam buku ilmu dakwah, pembukaan memiliki orientasi mengantarkan pikiran dan menambahkan perhatian kepada pokok pembicaraan. ${ }^{15}$ Dan mengantarkan pesan yang baik terhadap komunikator. ${ }^{16}$ Sedangkan isi pesan adalah inti pesan yang disampaikan dalam ceramah, cara penyampaian pesan ini bisa menggunakan cara deduktif dan cara induktif. Cara deduktif adalah cara menjelaskan materi dimulai dengan alur berpikir yang umum sedangkan induktif adalah cara menjelaskan dengan menggunakan materi yang khusus. ${ }^{17}$ Cara yang digunakan untuk mengembangkan isi pesan adalah dengan memberikan penjelasan seperti definisi ahli, definisi etimologis; contoh, analogi, testimoni, statistik, dan perulangan. ${ }^{18}$ Bagian penutup memiliki fungsi memfokuskan pikiran dan gagasan pendengar kepada gagasan utamanya. ${ }^{19}$ Oleh karena itu, penutup pidato harus dapat menjelaskan seluruh tujuan komposisi, memperkuat daya persuasi, mendorong pemikiran dan tindakan yang diharapkan, menciptakan klimaks dan menimbulkan kesan terakhir yang positif. $^{20}$

Ada beberapa cara yang biasa digunakan yakni menyampaikan ikhtisar; menyatakan kembali gagasan dengan menggunakan kalimat singkat; memberikan dorongan untuk bertindak;

\footnotetext{
17 Aziz, Ilmu Dakwah, 363.

18 Rakhmat, Retorika Modern., 27-30

19 Aziz, Ilmu Dakwah, 365.

20 Rakhmat, Retorika Modern., 59.
} 
mengakhiri dengan klimaks; menyatakan kutipan sajak, kitab suci, pribahasa, atau ucapan-ucapan ahli; menceritakan contoh-contoh; serta menjelaskan maksud sebenarnya pribadi pembicara. ${ }^{21}$

\section{Jenis Gaya Bahasa}

Gorys Keraf menyatakan bahwa gaya bahasa adalah cara mengungkapkan pikiran melalui bahasa secara khas yang memperlihatkan jiwa dan kepribadian penulis. ${ }^{22}$ Berdasarkan pada definisi di atas maka dapat dipastikan setiap orang pasti memiliki gaya bahasa yang berbedabeda. Gaya bahasa berdasarkan langsung tidaknya makna dibagi menjadi dua, yakni gaya bahasa retoris dan gaya bahasa kiasan. Gaya bahasa kiasan, adalah gaya bahasa yang memiliki makna yang tidak langsung atau makna yang bukan sebenarnya. Berikut ini ragam dan contoh gaya bahasa kiasan: (a) persamaan atau simile adalah perbandingan dua hal yang pada hakikatnya berlainan dan yang sengaja kita anggap sama. Perbandingan itu eksplisit dijelaskan dengan kata "seperti", "sama", "sebagai", "bagaikan", "laksana" dsb. Contoh: Seperti air dengan minyak; 23 (b) metafora adalah pemakaian kata-kata bukan arti yang sebenarnya, melainkan sebagai lukisan yang berdasarkan persamaan atau perbandingan. Metafora dapat menolong seorang pembicara atau penulis melukiskan suatu gambaran yang jelas melalui komparasi kontras, contoh: Nani jinak-jinak merpati, Ali mata keranjang; ${ }^{24}$ (c) personifikasi adalah kiasan yang

\footnotetext{
21 Aziz, Ilmu Dakwah, 365.

22 Gorys Keraf, Diksi dan Gaya Bahasa: Komposisi Lanjutan I. (Jakarta: Gramedia, 2009).
}

menggambarkan benda-benda mati atau barang-barang yang tidak bernyawa seolah-olah memiliki sifat-sifat kemanusiaan. Contoh: Hujan memandikan tanaman; (d) alegori adalah suatu cerita singkat yang mengandung kiasan. Orientasinya adalah untuk membuat pembaca semakin bergairah untuk menyingkap maksud dari cerita yang disampaikan, sehingga menimbulkan rasa keingintahuan tinggi; (e) ironis adalah gaya bahasa yang menyatakan sesuatu hal yang nyata berbeda, bahkan ada kalanya bertentangan dengan fakta sebenarnya. Ironi ringan merupakan bentuk humor, tetapi ironi berat termasuk sarkasme contoh: "O, kamu cepat bangun, baru pukul sembilan pagi sekarang ini."

(f) Pun atau paronomasia adalah kiasan dengan mempergunakan kemiripan bunyi. Tetapi sangat berbeda makna. Contoh: Oh, adinda sayang, akan kutanam bunga tanjung di Pantai Tanjung hatimu. (g) Satire adalah ungkapan yang menertawakan atau menolak sesuatu dan mengandung kritik tentang kelemahan manusia. Tujuannya adalah agar diadakan perbaikan secara etis maupun estetis; ( $h$ ) inuendo adalah sindiran dengan mengecilkan kenyataan yang sebenarnya. Orientasinya adalah kritik dengan sugesti tidak langsung dan sering tampaknya tidak menyakitkan hati. Contoh: Abangku sedikit gemuk karena terlalu kebanyakan makan daging berlemak; (i) anti frasis adalah ironi yang berwujud penggunaan sebuah kata dengan makna kebalikannya,

\footnotetext{
23 Henry Guntur Tarigan, Pengajaran Gaya Bahasa (Bandung: Angkasa Bandung, 1985), 9-10. 24 Ibid., 15-16.
} 
yang bisa saja dianggap sebagai ironi sendiri. Jika yang hadir kurus lalu dikatakan gendut, maka hal itu bertentangan dengan makna yang sebenarnya; (j) hipalase adalah suatu kebalikan dari suatu relasi alamiah antara dua komponen gagasan. Contoh: Aku menaiki kendaraan yang resah.

(k) Sinisme adalah suatu sindiran yang berbentuk kesangsian yang mengandung ejekan terhadap keikhlasan dan ketulusan hati, contoh: "Memang Andalah tokohnya yang sanggup menghancurkan desa ini dalam sekejap mata." (I) Sarkasme adalah suatu acuan yang mengandung kepahitan dan celaan yang getir, menyakiti hati, dan kurang enak didengar. Contohnya "Mulutmu harimaumu;" (m) metonimia adalah menggunakan nama ciri atau nama hal yang ditautkan dengan nama orang, barang atau hal, sebagai penggantinya. Contoh: Para siswa di kelas kami senang sekali membaca S.T. Alisyahbana; (n) sinekdoke adalah bahasa figuratif yang mempergunakan sebagian untuk menyatakan keseluruhan atau sebaliknya. Contoh: Setiap tahun semakin banyak mulut yang harus diberi makan di Tanah Air kita ini; (o) alusi adalah menyugestikan kesamaan antara orang, tempat atau peristiwa. Contoh: Tugu ini mengenangkan kita kembali ke peristiwa Bandung Selatan;

(p) Eponim adalah nama seseorang yang dihubungkan dengan sifat-sifat tertentu. Contoh: Hercules yang mengacu pada kekuatan, Vera-vera yang mengacu pada kebenaran; (q) epitet adalah semacam acuan yang menyatakan suatu sifat atau ciri yang khusus dari seseorang atau sesuatu hal. Keterangan itu merupakan suatu frasa deskriptif yang memerikan atau menggantikan nama sesuatu benda atau nama seseorang. Contoh: lonceng pagi bersahut-sahutan di desa terpencil ini menyongsong mentari bersinar menerangi alam. (lonceng pagi = ayam jantan); ( $r$ ) antonomasia sebuah bentuk khusus dari sinekdoke yang berwujud penggunaan sebuah epiteta untuk menggantikan nama diri, atau gelar resmi, atau jabatan untuk menggantikan nama diri. Contoh: Gubernur Sumatera Utara akan meresmikan pembukaan seminar Adat Karo di Kebanjahe bulan depan; (s) erotesis adalah pertanyaan yang dipergunakan dalam tulisan atau pidato untuk mencapai efek yang lebih mendalam dan penekanan yang wajar dan sama sekali tidak menuntut jawaban. Contoh: Soal ujian tidak sesuai dengan bahan pelajaran. Herankan kita jika nilai pelajaran Bahasa Indonesia pada UN tahun ini merosot?

Gaya bahasa retoris adalah gaya bahasa yang memiliki makna langsung. Jenisnya: (a) tautologi adalah menggunakan kata yang memiliki makna yang sama dengan kata sebelumnya. Contohnya, Kami tiba di rumah jam 04.00 subuh; (b) pleonasme adalah pemakaian kata yang mubazir (berlebihan), yang sebenarnya tidak perlu, indikasinya adalah apabila kata tersebut dihilangkan artinya tetap utuh. Contoh: Saya telah mencatat kejadian itu dengan tangan saya sendiri; (c) perifrasis adalah gaya yang mempergunakan kata lebih banyak dari yang diperlukan, indikasinya adalah kata-kata yang disampaikan itu sebenarnya bisa disampaikan dengan satu kata saja. 
Contohnya: Anak saya telah menyelesaikan kuliahnya di Jurusan Bahasa Indonesia FPBS-IKIP Bandung (= lulus dan berhasil); (d) antisipasi adalah penggunaan lebih dahulu kata-kata atau sebuah kata sebelum peristiwa atau gagasan yang sebenarnya terjadi. Contoh ketika ada wanita yang dirampok, penulis mengawali dengan kata: Wanita yang malang itu....; (e) koreksio adalah gaya yang berwujud mula-mula menegaskan sesuatu, tetapi kemudian memperbaikinya. Contoh: Dia benarbenar mencintai Neng Tetty, eh bukan, Neng Terry.

(f) hiperbol adalah gaya bahasa yang mengandung suatu pernyataan yang berlebih-lebihan jumlahnya, ukurannya atau sifatnya. Tujuannya adalah memberikan penekanan pada suatu pernyataan atau situasi untuk memperhebat, meningkatkan kesan dan pengaruhnya. Contoh: "Sempurna sekali, tiada kekurangan suatu apapun;" (g) litotes adalah gaya bahasa yang menyatakan hal positif dengan bentuk yang bertentangan untuk merendahkan diri atau mengurangi atau melemahkan kekuatan pernyataan yang sebenarnya. Contoh: Anak itu sama sekali tidak bodoh; (h) oksimoron adalah gaya bahasa yang mengandung pertentangan dengan mempergunakan kata-kata yang berlawanan dalam frasa yang sama. Contoh: Olahraga mendaki gunung memang menarik hati walaupun sangat berbahaya; (i) silepsis adalah gabungan gramatikal dua buah kata yang mengandung ciri-ciri semantik yang bertentangan. Contoh: Anak itu memang rajin dan malas di sekolah; (j) zeugma adalah konstruksi yang digunakan secara gramatikal benar akan tetapi secara semantik salah. Contoh: Adalah wanita itu kehilangan harta dan kehormatannya.

(k) Paradoks adalah gaya bahasa yang mengandung pertentangan yang nyata dengan fakta-fakta yang ada. Contoh: Aku kesepian di tengah keramaian; (I) Apostrof adalah semacam gaya yang berbentuk pengalihan amanat dari para hadirin kepada sesuatu yang tidak hadir. Contoh: Wahai dewa-dewa yang berada di nirwana, segeralah datang dan lepaskan kami dari cengkeraman yang durjana; (m) anastrof atau inversi adalah pembalikan susunan kata yang biasa dalam kalimat. Contoh: Diceraikannya istrinya tanpa setahu sanak-saudaranya; (n) apofasis adalah penulis atau pengarang menegaskan sesuatu, tetapi tampaknya menyangkal. Berpura-pura membiarkan sesuatu berlalu, tetapi sebenarnya ia menekankan hal itu. Contoh: "Saya tidak ingin menyingkapkan dalam rapat ini bahwa putrimu itu telah berbadan dua; (o) histeron proteron adalah kebalikan dari suatu yang logis atau kebalikan dari sesuatu yang wajar. Contoh: Pidato yang berapi-api pun keluarlah dari mulut orang yang berbicara terbata-bata itu.

(p) Eufemismus adalah ungkapanungkapan yang halus untuk menggantikan acuan-acuan yang mungkin dirasakan menghina, menyinggung perasaan atau menyugestikan sesuatu yang tidak menyenangkan. Contoh: tunaaksara, tunarungu; (q) elipsis adalah menghilangkan suatu unsur kalimat yang dengan mudah dapat diisi atau ditafsirkan 
sendiri oleh pembaca atau pendengar. Contoh: Nenek saya besok pagi; ( $r$ ) asidenton adalah berupa acuan, yang bersifat padat dan mampat di mana beberapa kata, frasa atau klausa yang sederajat tidak dihubungkan dengan kata sambung. Contoh: ayah, ibu, anak, merupakan inti suatu keluarga; (s) polisidenton adalah beberapa kata, frasa, atau klausa yang berurutan dihubungkan satu sama lain dengan kata-kata sambung. Contoh: Harga padi, jagung, dan sayur mayur sangat menggembirakan para petani tahun ini; (t) aliterasi adalah perulangan konsonan yang sama. Contoh: Biar bibir biduan berbicara; (u) asonansi adalah perulangan bunyi vokal yang sama. Contoh: Muka muda mudah muram; (v) kiasmus adalah berisikan perulangan dan sekaligus pula merupakan inversi hubungan antara dua kata dalam satu kalimat. Contoh: Yang kaya merasa miskin, sedangkan yang miskin justru merasa dirinya kaya. ${ }^{25}$

\section{Profil K.H. Zainuddin M.Z.}

K.H. Zainuddin M.Z., nama beliau tidak hanya mentereng sebagai seorang ulama, beliau juga mentereng dikenal sebagai politisi, juru kampanye, dan pendiri Partai Bintang Reformasi. Penceramah yang gemar membanyol dan mendongeng ini mengasah kemampuannya berpidato sejak belajar di Madrasah Aliyah Darul Ma'arif, Sekolah yang berafiliasi dengan Nahdlatul Ulama. Karena kemampuan

25 Keraf, Diksi dan Gaya., 130-145.

26 Desi Arditia Ningrum, Cerita KH Zainddin MZ dua minggu sebelum wafat, 28 Mei 2017 itulah beliau sering diundang ke pengajian dari kampung ke kampung dan menjadi terkenal.

Kiai yang wafat pada tanggal 5 Juli 2011 ini dalam setiap pidatonya diselipkan humor segar, sehingga membuat pendengar tidak merasa bosan. ${ }^{26}$ Termasuk dalam ceramah di desa Dongkal Tangerang Selatan tahun 2011. Ceramah yang mengangkat tema "Dengan Isra Mikraj Membangkitkan Semangat Keimanan dan Rasa Ukhuwah Islamiah Sesama Muslim" ini berdurasi 1 jam 09 menit 44 detik. Sedangkan studi gaya bahasa disini akan mengkaji gaya bahasa yang ada di setiap sesi, mulai dari pembukaan, isi, dan penutup ceramah. Dalam sesi isi, K.H. Zainuddin M.Z. menyelipkan tiga pesan, yakni Isra Mikraj adalah jaga iman baikbaik dan turunkan akidah kepada anak cucu; menjaga ukhuwah, persatuan dan kesatuan; serta ada hidup sesudah mati, sehingga tingkatkan keimanan dan ketakwaan kepada Allah SWT. Dalam analisis gaya bahasa pada isi pesan, studi ini menganalisis hanya pada isi pesan "Jaga Iman Baik-Baik dan Turunkan Akidah Kepada Anak Cucu".

\section{Analisis Gaya Bahasa K.H. Zainuddin M.Z.}

\section{Pembukaan Ceramah K.H. Zainuddin M.Z.}

Bagian pembuka adalah bagian yang berfungsi untuk mengantarkan pikiran dan menambatkan perhatian kepada pokok

https://www.merdeka.com/peristiwa/cerita-khzainuddin-mz-dua-minggu-sebelum-wafatramadan-2017.html 
pembicaraan. ${ }^{27}$ Pada bagian ceramah K.H. Zainuddin M.Z. yang mengantarkan pikiran kepada topik inti ada di menit 00.12-02.35. Pada menit tersebut beliau memberikan pengantar berupa permintaan maaf karena berbicara sambil duduk dan menyampaikan alasan, selain itu beliau juga meminta hadirin untuk memegang anaknya serta menurunkan balon yang dibawa dan menyampaikan topik yang akan dibahas pada pengajian peringatan Isra Mikraj pada saat itu.

Permintaan maaf disampaikan kepada hadirin karena beliau duduk di atas mimbar dengan menggunakan kursi, sedangkan para hadirin duduk lesehan di bawah. Alasannya beliau merasa kurang sehat karena tablig akbar di empat kota selama dua hari. Setelah itu, beliau menyebutkan tema pembahasan, "Dengan Isra Mikraj Meningkatkan Keimanan Dan Ukhuwah Islamiah". Penyebutan tema ini disampaikan agar pendengar memahami topik utama pembahasan. Menurut Jalaluddin Rakhmat pokok pembicaraan ini akan menjadi pusat perhatian khalayak. Berikut trankrip pembukaan ceramah K.H. Zainuddin M.Z..

"Saya mohon maaf bicaranya sambil duduk, karena sedikit kurang sehat pulang dari Bali, kemarin. Bukan jalan-jalan, tabligh akbar 4 kota di Bali selama dua hari. Karena itu mohon maaf saya bicaranya duduk dan nggak lama, paling maksa 5 menit dah. Biarin gua yang ngomong kenapa emang? (tertawa). Terus, saya mohon bantuan, bapak ibu yang bawa

27 Jalaluddin Rakhmat, Retorika Dakwah (Bandung: Remaja Rosdakarya, 1992), 53.

28 Ceramah K.H. Zainuddin M.Z., Waduh Ibu-lbu Ketawa Terpingkal-pingkal Ngakak-Live $\mathrm{KH}$. Zainuddin MZ, MP4 Video, 01.19-02.34 (Dongkal, anak, anaknya jangan berkeliaran! tolong dipegangin! yang megang balon, balonnya turunin!. Pegang di bawah, orang kagak liat gue, liat balon!. taruh di bawah neng, taruh! jangan dipegangin. Hoey! balon turunin hoey! lo kagak turunin, gua yang turun nih, gua pulang. (tertawa). Ibu bapak hadirin, ada tema di depan ini, dengan Isra' dan Mi'raj, meningkatkan keimanan dan ukhuwah Islamiah, dua hal itu yang jadi pembicaraan saya." ${ }^{28}$

Gaya bahasa pada pembukaan ceramah K.H. Zainuddin M.Z., adalah, pertama, oksimoron. Gaya bahasa oksimoron adalah gaya bahasa yang mengandung pertentangan dengan mempergunakan kata-kata yang berlawanan dalam satu kalimat. Pembukaan kalimat tersebut adalah "Bukan jalan-jalan, tablig akbar 4 kota di Bali." ${ }^{29}$ Di dalam kalimat tersebut terdapat dua kata yang bertentangan yakni "jalan-jalan" dan "tabligh akbar". Jalan-jalan memiliki makna bersenangsenang dengan berjalan kaki (untuk melepas ketegangan otot, pikiran, dan sebagainya) sedangkan "tabligh akbar" memiliki makna penyampaian ceramah agama. Dari makna tersebut dapat dilihat bahwa jalan-jalan merupakan aktivitas yang mengandung unsur hiburan dan cenderung menghabiskan uang, sedangkan tablig akbar merupakan bentuk pekerjaan yang berorientasi mendapatkan uang. Oleh karena itu gaya bahasa tersebut terdapat pertentangan. Dalam penyampaian, susunan kata setelah jalan-jalan terdapat konjungsi

Serpong, Tanggerang Selatan, 2018) https://www.youtube.com/watch?v=mftrf40MoOI $\& \mathrm{t}=21 \mathrm{~s}$.

29 Ibid., 01.30 
pertentangan seperti tetapi, akan tetapi K.H. Zainuddin M.Z. melesapkan konjungsi tersebut dan menggantinya dengan jeda. Jika dihubungkan dengan kedudukan pembuka yang membuat orang menarik untuk mendengarkan, dengan menggunakan premis "bukan jalan-jalan" membuat hadirin selanjutnya penasaran terhadap kegiatan yang dilakukan oleh K.H. Zainuddin M.Z., apalagi dengan kata "Bali" yang selama ini sebagai tempat wisata. Selain untuk meningkatkan rasa penasaran hadirin, gaya bahasa ini juga sebagai cara untuk meningkatkan kredibilitas pendakwah kepada hadirin.

Kedua, litotes. Gaya bahasa litotes adalah majas yang di dalam pengungkapannya menyatakan sesuatu yang positif dengan menyatakan pernyataan yang dikecilkecilkan, dikurangi dari kenyataan yang sebenarnya. Ungkapan atau pernyataan yang dikecilkan terdapat pada pembukaan yakni “... paling maksa 5 menit dah...." ${ }^{30}$. Kata "paling" memiliki arti "teramat" sedangkan "maksa" memiliki arti "mau tidak mau harus", "5 menit" adalah lama waktu yang dihabiskan untuk ceramah. Selama ini tidak ada ceramah secara live dilakukan dalam waktu 5 menit dan kenyataanya ceramah yang disampaikan oleh K.H. Zainuddin M.Z. berdurasi 1 jam 9 menit. K.H. Zainuddin telah mengecilkan rentang waktu penyampaian. Litotes tersebut digunakan untuk menurunkan ekspektasi hadirin yang ingin mendengarkan ceramah K.H. Zainuddin lebih lama. Penurunan ekspektasi ini sebagai salah satu cara untuk humor. Terbukti setelah disampaikan gaya bahasa litotes respon hadirin mengatakan "yaaah" yang menandakan keberatan, sedangkan respon K.H. Zainuddin pada kalimat setelahnya adalah "biarin gua yang ngomong" dan K.H. Zainuddin M.Z. tertawa.

\section{Isi Pesan Ceramah K.H. Zainuddin M.Z.}

Isi pesan adalah penjelasan topik pembicaraan, penjelasan topik ini diawali pada menit ke 02.36-56.25. Dalam penjelasan topik pembicaraan ada tiga hal yang dibahas yakni Isra Mikraj adalah peristiwa iman; menjaga persatuan dan kesatuan, serta menjalankan ibadah kepada Allah. Menit topik tersebut adalah 02.36-32.02. berdasarkan penjelasan sebelumnya di bagian metode penelitian, isi pesan yang akan dibahas adalah Isra Mikraj peristiwa tentang iman. Isi pesan akan dibahas sesuai dengan teknik pengembangan pesan yang digunakan K.H. Zainuddin M.Z. untuk menerangkan topik utamanya.

Pesan dakwah yang pertama, K.H. Zainuddin mengatakan bahwa Isra Mikraj adalah peristiwa iman. Oleh karena itu, umat Islam harus memercayainya karena akal tidak akan mampu menerima kenyataan tersebut. Pesan dakwah ini dijelaskan dengan mendetailkan alam yang telah dilalui Nabi sepanjang perjalanan dan memberikan contoh atau bukti tentang segala sesuatu yang tidak mungkin menjadi mungkin seperti kemunculan Nabi Adam dan kehamilan

30 Ibid., 01.41. 
Siti Maryam. ${ }^{31}$ Pesan dakwah selanjutnya adalah segala yang dimiliki oleh manusia hanyalah titipan. Oleh karena itu manusia tidak boleh sombong dan harus menjaga titipan dengan baik. Akibatnya jika tidak menjaga titipan, maka Allah akan marah dan akan menegur manusia melalui makhluknya yang lain.

Kemudian K.H. Zainuddin M.Z. juga menyampaikan ajakan untuk menjaga akidah. Ajakan ini diawali dengan penyampaian realitas banyaknya dukun yang memakai atribut kiai, kemudian banyak nabi-nabi palsu yang mengaku nabi palsu. Oleh karena itu manusia perlu disiplin, disiplin dalam menjaga akidahnya, disiplin waktu dengan salat dan disiplin hawa nafsu dengan puasa. Jika tidak menjaga akidah maka agama Islam akan tergerus dengan agama-agama yang lain. Cara untuk menjaga akidah adalah dengan memakmurkan majelis taklim, tidak jauh-jauh dari ustaz dan ulama, serta menghidupkan pengajian.

\section{a) Gaya Bahasa Pada Pesan Dakwah} "Isra Mikraj Adalah Peristiwa Iman"

Penggunaan penjelasan ini digunakan untuk memberikan gambaran kepada hadirin tentang peristiwa Isra Mikraj, sedangkan contoh atau bukti digunakan untuk menguatkan premis, "Peristiwa ini (Isra Mikraj) bukan ndak masuk akal. Bukan ndak masuk otak. Otak kekecilan...." Gaya bahasa Aliterasi terdapat pada teks "Nabi adam, bapak kagak, emak kagak, Allah mau, jadi enggak?". Gaya bahasa ini berupa perulangan konsonan yang sama yakni " $k$ " pada kata "bapak", "kagak", "emak", "enggak". Gaya bahasa ini ada di dalam pengembangan gagasan, digunakan untuk memperindah penyampaian. Dalam pengembangan isi pesan gaya bahasa ini digunakan untuk penekanan penjelasan dengan menggunakan bukti dari premis inti yakni Isra Mikraj adalah peristiwa iman.

Gaya bahasa asonansi juga digunakan pada teks "Nabi Isa, emak ada, bapak enggak ada". Gaya bahasa ini adalah gaya bahasa yang menggunakan pengulangan huruf vokal. Pengulangan tersebut terdapat pada vokal "a" pada kata "Isa", "ada". Penggunaan gaya bahasa aliterasi dan asonansi digunakan untuk memperindah sehingga tidak membuat hadirin merasa bosan. Hal ini dikarenakan premis yang disampaikan menguatkan gagasan inti sebelumnya. Oleh karena itu penggunaan gaya bahasa ini selaras dengan penyampaian gagasan inti dan berkedudukan sebagai pemberian bukti. Gaya bahasa erotesis juga digunakan K.H. Zainuddin M.Z., seperti "Jadi nggak?." pertanyaan ini tidak membutuhkan jawaban karena jawabannya hanya satu yakni "jadi". Pertanyaan ini digunakan untuk memberikan penegasan kepada hadirin mengenai bukti-bukti yang disampaikan K.H. Zainuddin M.Z.. Pertanyaan ini sudah tepat karena kedudukannya untuk menekankan kembali bukti-bukti yang sudah disampaikan sebelumnya.

\footnotetext{
31 Ibid., 04.58-05.04
} 


\section{b) Gaya Bahasa Pada Pesan Dakwah "Segala yang dimiliki oleh manusia hanyalah titipan"}

Untuk mengawali topik, K.H. Zainuddin

M.Z. menggunakan pengibaratan hidup seperti tukang parkir. Ini termasuk ke dalam gaya bahasa perumpamaan (simile). Gaya bahasa ini biasanya ditunjukkan dengan kata seperti atau kayak dan lain-lain, akan tetapi dalam penyampaian K.H. Zainuddin tidak eksplisit menyampaikan hal tersebut. Pada teks K.H. Zainuddin M.Z., terdapat persamaan dua hal yakni pekerjaan tukang parkir disamakan dengan manusia yang sama-sama diberikan titipan. Perumpamaan digunakan oleh K.H. Zainuddin M.Z. untuk mempermudah sebuah penjelasan tentang konsep tasawuf. Perumpamaan ini menurut penulis sudah tepat, karena pengambilan perumpamaan memiliki kemiripan dan sesuai dengan kesimpulan akhirnya yakni semua yang dimiliki manusia adalah titipan dan tidak boleh sombong.

Gaya bahasa erotesis juga disampaikan oleh K.H. Zainuddin M.Z. untuk mempertegas subjek yang memberikan titipan. Gaya erotesis adalah sejenis gaya bahasa yang berupa pertanyaan yang dipergunakan dalam tulisan atau pidato yang bertujuan untuk mencapai efek yang lebih mendalam dan penekanan yang wajar. Gaya bahasa ini diindikasikan dengan kalimat pertanyaan dengan satu kemungkinan jawaban. Kalimat pertanyaan tersebut adalah "siapa yang nitip?" 32 jawaban yang ada hanya satu yakni "Allah". Selain untuk mempertegas juga digunakan untuk memperindah gaya bahasa karena jika langsung disampaikan subjek yang memberi titipan, maka ceramah akan terasa datar dan mengulang sesuatu yang sudah jelas jawabannya.

Eponim juga digunakan K.H. Zainuddin M.Z. untuk menjelaskan pejabat yang sombong. Gaya bahasa eponim adalah gaya bahasa yang mengandung nama seseorang yang begitu sering dihubungkan dengan sifat tertentu sehingga nama itu dipakai untuk menyatakan sifat tertentu. Nama seseorang yang dimaksud adalah Fir'aun, dalam ceramah K.H. Zainuddin M.Z., tidak dihubungkan dengan Fir'aun secara langsung akan tetapi ditambahkan kata "anak" yang berarti keturunan dari Fir'aun. Keturunan biasanya mewarisi sifat-sifat yang dimiliki oleh kedua orang tuanya, oleh karena itu anak Fir'aun berarti pejabat tersebut memiliki sifat yang sama dengan Fir'aun, "tuh, pejabat sombong anak Firaun tuh". ${ }^{33}$ Eponim ini ditunjukkan dengan penyebutan nama seseorang yang dihubungkan dengan sifat tertentu. K.H. Zainuddin M.Z. menyampaikan nama Fir'aun untuk menunjukkan penguasa yang memiliki sifat sombong. Orientasi penggunaan gaya bahasa ini untuk memberikan sindiran terhadap pejabat-pejabat yang sombong karena teks tersebut menyatakan bahwa pejabat yang sombong anak Fir'aun. Sindiran ini termasuk sindiran halus.

\footnotetext{
33 Ibid., 09.17
} 
Selain itu gaya bahasa paradoks juga digunakan K.H. Zainuddin M.Z. untuk mengejek orang yang sombong, dengan kalimat "mentang-mentang kaya jalan nggak nginjek tanah" ${ }^{34}$. Gaya bahasa paradoks adalah gaya bahasa yang mengandung pertentangan yang nyata dengan fakta-fakta yang ada. K.H. Zainuddin M.Z. mempertentangkan orang kaya yang jalannya tidak menginjak tanah. Padahal kenyataannya setiap manusia kalau jalan pasti menginjak tanah, sehingga pernyataan tersebut merupakan hal yang bertentangan. Selain digunakan untuk menyindir, gaya bahasa paradoks ini digunakan K.H. Zainuddin untuk membuat humor hadirin terbukti dengan setelah beliau menyebutkan paradoks tersebut hadirin tertawa. Humor dalam penyampaian pesan dakwah diperlukan agar penjelasan tidak monoton dan terkesan menimbulkan suasana santai.

\section{c) Gaya bahasa pesan dakwah "Manusia} yang tidak menjaga titipan, akan ditegur oleh Allah melaui makhluk-Nya yang lain" Gaya bahasa asidenton adalah gaya bahasa yang berupa acuan padat dan mampat, dimana beberapa kata, frasa atau klausa yang sederajat tidak dihubungkan dengan kata sambung. Penjelasan gagasan tentang titipan tidak dijaga dengan baik akan membuat pihak yang nitip marah menggunakan ilustrasi seseorang yang menitipkan motornya. Di dalamnya terdapat perincian tentang hasil penjagaan yang tidak baik seperti "kaca spion pecah, knalpot ilang, bemper penyok". ${ }^{35}$ Perincian tersebut tidak

\footnotetext{
34 Ibid., 09.48

35 Ibid., 10.28

36 Ibid., 11.12
}

menggunakan kata sambung "dan" tetapi dipisahkan dengan jeda pendek. Oleh karena itu pada teks tersebut disebut gaya bahasa asidenton. Gaya bahasa tersebut juga terdapat pada pernyataan K.H. Zainuddin untuk merincikan pekerjaan anak yang menjadi titipan bagi manusia seperti "nyatu mabok, nyatu nyolong, nyatu ngerampok". ${ }^{36}$ Tujuan penggunaan gaya bahasa ini untuk memperindah penyebutan rincian. Penggunaan asidenton menunjukkan kesetaraan dengan tingkat kepentingan yang sama, selain itu juga membuat suasana menjadi santai, karena tanpa kata sambung menjadi salah satu ciri bahasa percakapan, yang cocok untuk suasana santai.

Gaya bahasa erotesis juga digunakan pada kalimat pertanyaan "yang nitip?" 37 Jawaban "marah" adalah jawaban satusatunya, tidak ada jawaban lain selain kata tersebut. Penggunaan erotesis ini digunakan untuk memberikan efek yang lebih mendalam dan penekanan yang wajar. Dalam penyampaian pesan gaya bahasa erotesis ini bisa membuat ruang hadirin memberikan feedback, meskipun jawabannya sudah memiliki kepastian. Gaya bahasa ini sudah tepat karena bisa menunjukkan penekanan pada gagasan inti yakni kalau titipan tidak dijaga, orang yang nitip marah. Gaya bahasa hiperbola juga digunakan dalam penyampaian gagasan "titipan harus dijaga dengan baik". Teks gaya bahasa tersebut adalah "pelitnya tujuh belas syaithan". ${ }^{38}$ Dalam teks tersebut terdapat pernyataan yang

\footnotetext{
37 Ibid., 11.15

38 Ibid., 11.41
} 
berlebih-lebihan jumlahnya seperti "tujuh belas syaitan". Satu orang setan dianggap pelit apalagi ada tujuh belas setan. Gaya bahasa hiperbola yang lain adalah "bu, seratus tahun kita bangun, selesai oleh gempa 5 menit". ${ }^{39}$ Bentuk berlebihan dalam teks tersebut adalah "seratus tahun" menunjukkan betapa lamanya pembangunan di Jepang dan "selesai oleh gempa 5 menit" menunjukkan betapa singkatnya bencana tersebut. Tujuan penggunaan gaya bahasa ini untuk menunjukkan kehebatan sekaligus penekanan contoh yang disampaikan K.H. Zainuddin M.Z.. Menurut penulis penggunaan hiperbola tepat karena menekankan pesan begitu dasyatnya dampak orang yang tidak menjaga titipan dengan baik.

Selain memberikan ilustrasi, beliau juga memberikan contoh titipan yang lain, yakni Negara. "hai rakyat, ini Indonesia aku titip kata Allah, titipan ini ditebus dengan keringat, air mata, darah, dan nyawa. ini Negara besar dan kaya. Besar dan kaya. Kekayaannya dikuasai oleh Negara. Tetapi harus digunakan bagi sebesar-besar kemakmuran rakyat. Disalahgunakan, dikorupsi, yang nitip?" 40 Untuk menjelaskan itu beliau menggunakan drama seolah-olah Allah mengatakan pesan kepada rakyat Indonesia secara langsung. Gaya bahasa yang digunakan ini adalah gaya personifikasi. Personifikasi adalah jenis gaya bahasa yang melekatkan sifat-sifat insani kepada barang yang tidak bernyawa dan ide yang abstrak. Dalam teks tersebut yang dimaksud sesuatu yang

39 Ibid., 14.00 abstrak adalah Allah yang berpesan atau berbicara selayaknya manusia dengan memberikan titipan berupa Negara. Dalam kalimat tersebut melekatkan karakteristik insani yakni berbicara terhadap sesuatu yang abstrak (Allah). Orientasi penggunaan gaya bahasa ini adalah agar memudahkan hadirin dalam mengilustrasikan maksud dari K.H. Zainuddin M.Z. jika bentuk titipannya berupa Negara.

Gaya bahasa epitet terdapat pada kata "ditebus dengan keringat, air mata, darah, dan nyawa". Epitet adalah semacam acuan yang menyatakan suatu sifat atau ciri yang khusus dari seseorang atau sesuatu hal. Keterangan itu merupakan suatu frasa deskriptif yang memerikan atau menggantikan nama sesuatu benda atau nama seseorang. Ciri khusus suatu hal terdapat pada kata "keringat, air mata, darah dan nyawa" yang menggantikan kata "perjuangan yang menguras tenaga dan psikologis serta dapat menimbulkan resiko terluka, cacat bahkan kehilangan nyawa". Penggunaan gaya epitet ini digunakan dalam rangka untuk menggambarkan perjuangan yang luar biasa rakyat Indonesia agar bisa merdeka

Dalam teks tersebut, K.H. Zainuddin M.Z. juga berusaha menghadirkan Allah dan seluruh rakyat Indonesia berada dalam satu lokasi, akan tetapi peristiwa tersebut tidak ada, hanya khayalan yang diciptakan oleh beliau untuk menggambarkan situasi Allah yang menitipkan Negara Indonesia kepada seluruh rakyat Indonesia. Dalam penyampaiannya K.H. Zainuddin M.Z.

40 Ibid., 11.37 
menggunakan gaya bahasa sinekdoke totem pro parte yakni gaya bahasa figurative yang mempergunakan keseluruhan untuk menyatakan sebagian (totem pro parte). Objek perkataan adalah seluruh rakyat Indonesia yang seolah-olah hadir dalam acara tersebut, padahal kenyataannya hanya sebagian kecil saja. Gaya bahasa ini digunakan untuk menunjukkan keindahan penyampaian serta menunjukkan keluhuran karena yang menitipkan adalah Allah.

Gaya bahasa personifikasi terdapat pada kata "Merapi, meletup. Bromo, muntah. Anak Krakatau meriang", "Merapi tuh demo tuh, demo". Gaya personifikasi adalah jenis majas yang melekatkan sifatsifat insani kepada barang yang tidak bernyawa dan ide yang abstrak. Penyamaan sifat-sifat manusia pada benda mati yakni "muntah" berarti keluar kembali makanan dan minuman yang masuk ke dalam perut dan "meriang" berarti berasa tidak enak badan karena kurang sehat misalnya masuk angina atau karena influenza. Kedua kata tersebut digunakan untuk manusia. Kata-kata tersebut digunakan pada kata "krakatau", "Merapi", "Bromo" yang merupakan benda mati. Orientasi Gaya tersebut digunakan untuk mempermudah abstraksi hadirin dalam menggambarkan kemarahan alam. Hal ini dikarenakan tiga contoh yang disampaikan adalah samasama gunung, perilaku gunung bisa beragam ada yang mengeluarkan awan panas atau lava. Agar tidak terkesan monoton pengucapannya K.H. Zainuddin M.Z. menggunakan personifikasi agar kata yang disampaikan bisa lebih variatif dan tidak terkesan membosankan. hadirin juga bebas untuk menggambarkan kondisi gunung yang sedang muntah dan meriang. Kata tersebut jika dihubungkan dengan gagasan inti, kedudukannya sebagai contoh, dan penggunaan contoh tersebut sudah tepat karena mampu menggambarkan bentuk dampak yang akan terjadi jika tidak menjaga titipan dengan baik.

d) Gaya Bahasa pada Pesan "Manusia Perlu Allah dan Isra Mikraj Adalah Kemauan Allah"

Gaya bahasa hiperbola terdapat pada teks "salat malam sampai kakinya bengkak". ${ }^{41}$ Kata "bengkak" menunjukkan Nabi rajin sujud. Sedangkan salat malam sampai kaki bengkak adalah sesuatu hal yang tidak mungkin dan itu termasuk ke dalam penggunaan kata berlebihan. Orientasi K.H. Zainuddin M.Z. menggunakan gaya bahasa tersebut untuk menunjukkan kehebatan Rasulullah dalam menjalankan ibadah. Penyampaian gaya bahasa tersebut dalam kesatuan pesan gagasan berkedudukan sebagai penjelas yang mengantarkan pada inti pesan yakni "kita perlu Allah", dengan gaya bahasa hiperbola membuat suasana sebelum inti pesan kesannya semakin meningkat. Menurut penulis hal itu sudah selaras karena menimbulkan kesan yang semakin lama semakin meninggi.

e) Gaya Bahasa Pada Pesan "Islam mengajarkan disiplin, yakni disiplin akidah, disiplin waktu dengan salat dan disiplin hawa nafsu dengan puasa"

41 Ibid., 15.28 
Gaya bahasa yang digunakan K.H. Zainuddin M.Z., adalah gaya bahasa erotesis yakni gaya bahasa yang mengandung pertanyaan retoris, kalimat pertanyaan yang mengandung satu kemungkinan jawaban. Gaya bahasa tersebut terdapat pada teks "apa semua yang kuning pasti emas?" 42, dalam pertanyaan tersebut hanya terdapat satu jawaban yakni "tidak". Fungsi yang ingin dicapai dalam teks tersebut adalah penegasan pernyataan karena kalimat sebelumnya beliau menyampaikan pemburu hantu yang menggunakan atribut kiai (serban) dampak jika atribut kiai dipakai oleh pemburu hantu adalah kedudukan pemburu hantu yang akan disamakan dengan kiai padahal secara substansi sudah berbeda. oleh karena itu untuk menunjukkan perbedaan tersebut menggunakan pertanyaan erotesis. Selain fungsi penegasan, pertanyaan erotesis juga untuk humor dengan hadirin. Terbukti setelah beliau menggunakan kalimat erotesis tersebut hadirin tertawa. Warna kuning merupakan warna yang diasosiasikan dengan apa saja.

Gaya metonimia juga digunakan oleh K.H. Zainuddin M.Z.. Gaya bahasa ini adalah gaya bahasa yang memakai nama ciri atau nama hal yang ditautkan dengan nama orang, barang, atau hal, sebagai penggantinya. Indikasinya adalah kata "serban" yang memiliki makna penutup kepala yang digunakan oleh kiai, dan menyimbolkan sesuatu yang agamis. "serban" mengandung gaya bahasa metonimia, selain itu kata "minyak babi" sebagai simbol haram sedangkan "cap unta" sebagai simbol halal. Dalam pemberian gaya bahasa metonimia ini digunakan untuk memudahkan penggambaran hadirin terhadap maksud "jaman entertain". Pemilihan metonimia "serban", "babi", "unta" untuk penggambaran penjabaran terhadap sesuatu yang berkebalikan menurut penulis sudah tepat, karena premis sebelumnya sudah menunjukkan contoh konkret penggunaan simbol-simbol yang tidak sesuai dengan kedudukannya.

Gaya bahasa perumpamaan terlihat di awal penjelasan yakni pada teks "serbannya kayak batman". kata "kayak" sama halnya dengan kata "seperti", perumpamaan ini digunakan karena batman juga memiliki kain panjang dipunggungnya untuk terbang. Dalam hal ini beliau mengandaikan jika serbannya yang dipakai panjangnya sama dengan batman. Sebagaimana diketahui bahwa serban diletakkan di kepala, sedangkan Batman berada dipunggungnya, kesamaan yang ada antara serban dengan batman adalah serbannya menjulur panjang seperti serbannya batman. Penggunaan perumpamaan ini untuk menggambarkan atribut yang digunakan oleh pemburu hantu sangat panjang, akan tetapi pilihan kata "batman" yang merupakan tokoh film fiksi membuat hadirin tertawa. Perumpamaan dengan batman untuk kemudahan pemahaman sekaligus sebagai humor.

Gaya bahasa paradoks terdapat pada teks "polisi kita hebat, Jibril saja ditangkap". Gaya bahasa paradoks adalah gaya

42 Ibid., 16.55 
bahasa yang mengandung pertentangan yang nyata dengan fakta-fakta yang ada. "Jibril" adalah malaikat (makhluk imateriel) yang bertugas menyampaikan wahyu. Sedangkan "Jibril" yang disampaikan oleh K.H. Zainuddin M.Z. adalah "Jibril" yang bisa ditangkap oleh polisi. Faktanya malaikat tidak akan bisa ditangkap oleh polisi. Oleh karena itu teks tersebut mengandung pertentangan yang nyata dengan fakta-fakta yang ada. Gaya bahasa paradoks tersebut digunakan untuk humor, terbukti hadirin juga memberikan respons dengan tertawa. Penggunaan paradoks ini tepat penggunaannya karena sebelumsebelumnya K.H. Zainuddin M.Z. membahas hal yang serius yakni menyampaikan bukti banyak munculnya nabi dan malaikat palsu, dengan adanya paradoks ini membuat suasana lebih cair.

\section{f) Gaya Bahasa pada Pesan "Anjuran Orang Tua Untuk Menurunkan Akidah Kepada Anak"}

Gaya bahasa hiperbola adalah gaya bahasa yang mengandung pernyataan yang berlebih-lebihan, jumlahnya, ukurannya atau sifatnya, dengan maksud memberi penekanan pada suatu pernyataan atau situasi untuk memperhebat, meningkatkan kesan dan pengaruhnya. Gaya bahasa tersebut terdapat pada teks "biarin Mak lu Bapak lu kepala jadi kaki, kaki jadi kepala". Teks tersebut melebihlebihkan perilaku orang tua yang berupaya untuk menyekolahkan anaknya. "Kepala menjadi kaki" itu adalah sesuatu hal yang tidak mungkin, dan sebaliknya. Selain itu dalam teks sebelumnya "kerja keras" dan "peras keringat". Gaya bahasa tersebut termasuk hiperbola karena di dalamnya mengandung idiom yang mengandung makna berlebihan terhadap kata giat bekerja.

Gaya bahasa ellipsis adalah penghilangan salah satu atau beberapa unsur penting dalam konstruksi sintaksis yang lengkap. Gaya bahasa ini juga digunakan oleh K.H. Zainuddin M.Z. pada saat menyebutkan "keong racun". Keong racun yang dimaksud adalah lagu, K.H. Zainuddin M.Z. menghilangkan kata lagu, karena dianggap masyarakat sudah mengetahui makna "keong racun" yang mengacu pada lagu. Karena sebelumnya beliau menjelaskan bahwa bayi yang baru lahir pertama kali yang didengarkan adalah azan. Sehingga pembahasan sebelumnya adalah pembahasan tentang sesuatu yang didengar. Dalam bahasa percakapan, ellipsis ini digunakan karena dianggap antara pendengar dan pembicara sudah sama-sama mengetahui konteks pembicaraan. Gaya ellipsis tersebut membuat suasana menjadi lebih cair.

Selain itu juga gaya bahasa ellipsis juga digunakan yakni "jadi petani, petani beriman, jadi artis artis beriman, jadi maling (diam)". Kata yang hilang adalah "maling beriman". Hal ini bisa dilihat dari struktur sebelumnya yang menggunakan gaya bahasa repetisi anadiposis yakni gaya bahasa yang mengulang kata "beriman". Elipsis ini mampu membuat hadirin tertawa, oleh karena itu fungsi gaya bahasa ini untuk membuat humor hadirin, selain itu juga digunakan untuk memberikan kesempatan hadirin memberikan feedback. 
g) Gaya Bahasa pada Pesan "Manusia setiap hari menemukan halal haram, benar, salah, hak dan batil"

Penyampaian pesan dakwah tersebut, K.H. Zainuddin M.Z. menggunakan gaya bahasa asidenton, hal itu terdapat pada kalimat "kamu pilih, kamu ambil, kamu minum". Asidenton adalah gaya bahasa yang berupa acuan padat dan mampat, dimana beberapa kata, frasa, klausa tidak dihubungkan dengan kata sambung. Pada teks tersebut terdapat tiga klausa yang terdiri dari "kamu pilih", "kamu ambil", "kamu minum". Ketiga klausa tersebut tidak dihubungkan kata hubung sama sekali. Selain itu ketiga klausa tersebut merupakan urutan perilaku sebelum meminum yakni memilih, mengambil, kemudian meminum. Dalam susunan tersebut kata "ambil" secara komponen makna sudah tercakup dalam kata "minum", sehingga menurut penulis tidak perlu disebutkan kata "ambil" tidak akan mengurangi maksud dari pembicara. Akan tetapi untuk menekankan prosesnya K.H. Zainuddin M.Z. lebih memilih untuk mendetailkan urutan perilakunya. Kata yang sebenarnya tidak perlu ada, kemudian dimunculkan oleh K.H. Zainuddin M.Z. disebut gaya bahasa perifrasis.

Fungsi dari kedua gaya bahasa tersebut adalah untuk menunjukkan kesetaraan sehingga menunjukkan tingkat kepentingan yang sama, selain itu juga digunakan untuk menekankan ucapan. Jika dihubungkan dengan kalimat sebelumnya kedudukannya sebagai penjelas, bagi hadirin penggunaan kata khusus tersebut akan lebih memudahkan membayangkan perilaku Nabi
Muhammad secara detail sebelum meminum dua minuman yang diajukan oleh Jibril.

\section{h) Gaya bahasa pada Pesan "Anjuran Untuk Tidak Jauh-Jauh Dari Ulama Atau Ustaz"}

Gaya bahasa yang digunakan dalam bagian akhir isi pesan adalah paronomasia, hal itu terdapat pada teks "buk, ibu kalau ada racun ada madu, ibu pilih diracun apa dimadu?." Paronomasia adalah penggunaan kata yang berbunyi sama akan tetapi bermakna lain. Pada kata "madu" terdapat dua makna, yakni cairan yang dihasilkan oleh lebah dan bermakna istri kedua dari suami berdasarkan sudut pandang istri pertama. Kata tersebut termasuk polisemi dan digunakan oleh K.H. Zainuddin M.Z. untuk membuat humor, terbukti setelahnya hadirin tertawa. Gaya bahasa asidenton juga terdapat pada teks "... kurang teliti, cepet heran gampang kagum, mudah terpesona, mudah terbuai". Teks tersebut terdapat 5 klausa yakni "kurang teliti", "cepet heran", "gampang kagum", "mudah terpesona", "mudah terbuai". Kelima klausa tersebut tidak dihubungkan dengan kata sambung. Kata-kata tersebut merupakan sinonim satu dengan yang lain. penggunaan kata tersebut prinsipnya hanya satu yakni mudah kagum, akan tetapi oleh K.H. Zainuddin M.Z. digunakan untuk memberikan penekanan pesan, sekaligus untuk membuat keindahan dalam berceramah. Sehingga menimbulkan kesan yang berbeda di setiap penyebutan sinonim yang selainnya.

Gaya metonimia juga muncul lagi di akhir penjelasan, dengan kata "madu" yang 
merujuk pada sesuatu yang baik sedangkan "racun" merujuk pada sesuatu yang buruk. Hal ini digunakan untuk memahamkan hadirin. Gaya bahasa yang disebutkan di atas sudah tepat, karena pengembangan pesan ini merupakan pengulangan dari pesan sebelumnya, dengan menggunakan gaya bahasa yang mengandung humor menunjukkan kesan yang berbeda dibandingkan sebelumnya.

\section{Penutup Ceramah}

Penutup merupakan bagian akhir dari ceramah, penutup ini berada pada menit ke 1.06.00-1.09.45, indikasi penutup adalah beliau menyebutkan rangkuman yang merupakan hasil ikhtisar dari keseluruhan pembahasan. Indikasi rangkuman adalah dengan merincikan "pertama, kedua ketiga dan seterusnya." Rangkuman ini disampaikan agar hadirin tidak melupakan pesan yang telah disampaikan oleh K.H. Zainuddin M.Z. sebelumnya. Selain itu juga berfungsi untuk menekankan pesan kembali agar hadirin senantiasa mengingat pesan tersebut. Berikut transkrip penutup pesan K.H. Zainuddin M.Z.

"Pertama, rangkuman, pertama, jaga iman baik-baik wariskan kepada anak-anak kita. Biarin zaman berobah, akidah jangan goyah boleh masa berganti keyakinan jangan mati. Karena iman kita hidup, untuk iman kita berjuang, Dalam iman kita ingin kembali menghadap Allah SWT, satu. Yang kedua Jaga kesatuan persatuan, kerukunan, ibu tau lidi?,lidi biar gede banget, kalau sendirian laler kagak mati, biar lidi kecil digabung ama lidi yang lain, diiket jadi satu, sapu namanya, jangan laler anjing juga gempor." 43
Gaya bahasa yang digunakan pada penutup ceramah, di antaranya adalah gaya bahasa asonansi, digunakan oleh dalam teks "Zaman berobah, akidah jangan goyah, boleh masa berganti keyakinan jangan mati." Teks tersebut terdapat pengulangan huruf vokal "a" dalam setiap kata. Fungsi dari gaya bahasa ini adalah membuat indah kalimat dan menekankan pesan. Gaya bahasa tersebut tepat dan selaras dengan kedudukan kalimat yang berada pada bagian penutup. Gaya bahasa metonimia juga digunakan untuk menjelaskan persatuan, kesatuan, kerukunan dengan "lidi". Lidi memiliki kesamaan dengan persatuan, karena lidi terdiri dari kumpulan ijuk yang diikat, sedangkan kesatuan merupakan kumpulan orang-orang bersatu. Lidi memiliki kesamaan sifat dengan kesatuan. perumpamaan tersebut mudah dipahami karena perumpamaan itu sudah umum di masyarakat. Meskipun sudah umum, beliau kemudian menambahkan penjelasan perumpamaan tersebut dengan hiperbola yakni “jangan laler anjing juga gempor". Laler memiliki makna hewan yang kecil sedangkan anjing merupakan hewan yang besar, gempor menunjukkan bahwa anjingnya babak belur kesakitan. Hiperbola menunjukkan penekanan terhadap pesan ajakan untuk menjaga kesatuan dan persatuan dan dampaknya jika bersatu. Gaya bahasa ini sudah tepat karena menjelaskan ringkasan dari pesan-pesan sebelumnya.

Dari pemaparan di atas dapat dilihat bahwa K.H. Zainuddin M.Z. menggunakan variasi gaya bahasa dalam menyampaikan

43 Ibid., 56.25 
gagasannya. Gagasan yang dianggap sulit beliau menggunakan perumpamaan selain itu juga menggunakan metonimia untuk menjelaskan. Sedangkan untuk humor, K.H. Zainuddin M.Z. memiliki banyak variasi yakni oksimoron, litotes, perumpamaan, ellipsis, paronomasia dan metonimia. Sedangkan untuk memperindah pesan, K.H. Zainuddin M.Z. menggunakan asonansi, sinekdoke totem pro parte, erotesis, dan aliterasi. Sedangkan untuk menunjukkan kehebatan atau keluarbiasaan sesuatu K.H. Zainuddin M.Z. menggunakan gaya bahasa hiperbola. Untuk menyindir sesuatu K.H. Zainuddin lebih cenderung menggunakan gaya paradoks dan eponim yang berisi sindiran secara halus. Tidak jarang beliau menggunakan satu gaya bahasa untuk dua tujuan atau lebih seperti oksimoron, aliterasi, erotesis, asidenton, metonimia, asonansi dan hiperbola.

Tabel 1 - Gaya bahasa berdasarkan langsung tidaknya makna K.H. Zainuddin M.Z..

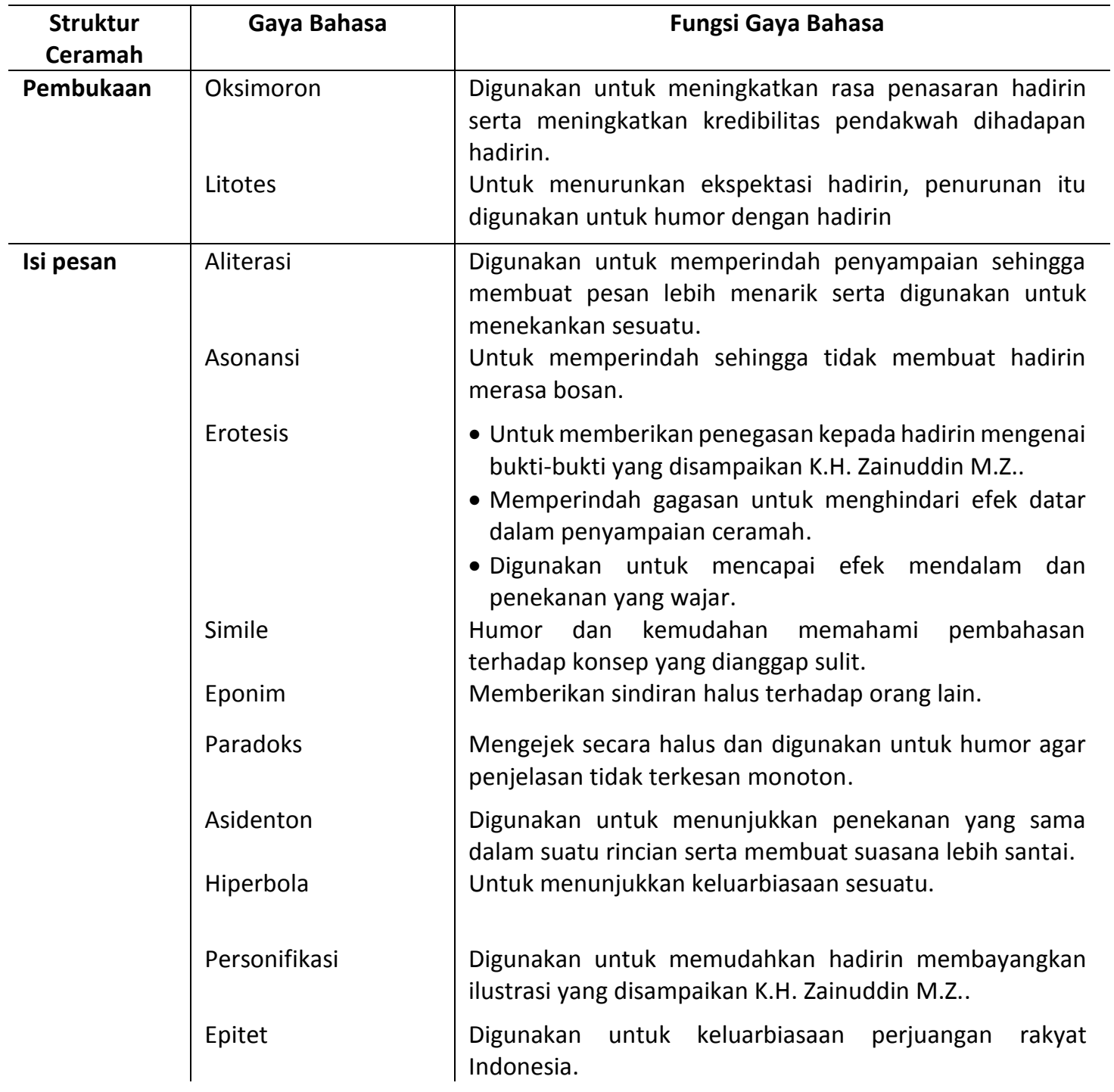




\begin{tabular}{|c|c|c|}
\hline Struktur & Gaya Bahasa & Fungsi Gaya Bahasa \\
\hline & $\begin{array}{l}\text { Sinekdoke totem pro } \\
\text { parte } \\
\text { Metonimia } \\
\text { Elipsis } \\
\text { Perifasis } \\
\text { Paronomasia }\end{array}$ & $\begin{array}{l}\text { Untuk memperindah suatu pernyataan dan keluhuran. } \\
\text { Digunakan untuk memudahkan pemahaman terhadap } \\
\text { realitas sekaligus sebagai humor. } \\
\text { Digunakan untuk menghindari pengucapan yang sama } \\
\text { sehingga membuat hadirin tidak merasa bosan, selain itu } \\
\text { juga digunakan untuk membuat suasana lebih cair. Fungsi } \\
\text { lainnya adalah untuk humor. } \\
\text { Untuk menunjukkan tingkat kepentingan yang sama serta } \\
\text { memudahkan hadirin dalam membayangkan pesan yang } \\
\text { disampaikan oleh K.H. Zainuddin M.Z.. } \\
\text { Digunakan untuk humor. }\end{array}$ \\
\hline Penutup & $\begin{array}{l}\text { Asonansi } \\
\text { Metonimia } \\
\text { Hiperbola }\end{array}$ & $\begin{array}{l}\text { Untuk keindahan penyampaian dan digunakan untuk } \\
\text { menekan isi pesan. } \\
\text { Digunakan untuk memudahkan pemahaman terhadap } \\
\text { konsep yang lebih abstrak. } \\
\text { Untuk penekanan dan menunjukkan keluarbiasaan } \\
\text { sesuatu. }\end{array}$ \\
\hline
\end{tabular}

\section{Kesimpulan}

Berdasarkan pada analisis di atas didapatkan bahwa K.H. Zainuddin M.Z. menggunakan gaya bahasa litotes dan oksimoron pada bagian pembukaan pesan. Gaya bahasa litotes digunakan untuk meningkatkan rasa penasaran dengan hadirin. Gaya bahasa oksimoron digunakan untuk meningkatkan kredibilitas pendakwah di hadapan hadirin. Hal ini telah sesuai dengan tujuan pesan pembukaan yaitu meningkatkan kredibilitas dan membangun kemenarikan. Sedangkan pada bagian isi pesan, K.H. Zainuddin M.Z. pengembangan pesan dengan menggunakan contoh dan ilustrasi serta menyampaikan bukti-bukti. Beliau menggunakan gaya bahasa yang lebih variatif yang digunakan untuk memberikan pemahaman seperti metonimia dan perumpamaan. Sedangkan untuk humor, beliau menggunakan gaya bahasa oksimoron, litotes, perumpamaan, ellipsis, paronomasia dan metonimia. Selain itu gaya bahasa yang berorientasi untuk membuat menarik penyampaian ceramah adalah asonansi, sinekdoke totem pro parte, erotesis, dan aliterasi. Untuk menyindir secara halus beliau juga menggunakan paradoks dan eponim. Penggunaan keseluruhan gaya bahasa selaras dengan pengembangan pesan tersebut. Pada bagian penutup pesan K.H. Zainuddin M.Z. menggunakan cara mengulang kembali prinsip-prinsip yang telah dijelaskan sebelumnya dan menyampaikan ikhtisar dengan menggunakan pengurutan dalam penutupan beliau menggunakan gaya bahasa asonansi dan hiperbola untuk keindahan dan penekanan penutup. 
Gaya bahasa yang digunakan tersebut sudah tepat, karena sesuai dengan maksud yang disampaikan dan mendukung kemenarikan dari ceramah, kemenarikan itu dengan menunjukkan kehebatan dan humor yang digunakan untuk penyegaran pada bagian isi pesan atau pengembangan pesan sebelumnya yang berisi inti pesan atau penekanan. Harapannya bagi studi selanjutnya, dengan pemahaman tentang gaya bahasa ini bisa dijadikan sebagai salah satu referensi untuk melakukan kajian lanjutan terhadap komunikasi ceramah, atau sebagai pijakan mempelajari sisi komunikasi di luar sisi kebahasaan.

\section{Bibliografi}

Andriani, Viviana Pratiwi. "Analisis Diksi dan Gaya Bahasa Ceramah Ust. Abdul Somad di Masjid Al-Jihad Medan." Skripsi, Universitas Muhammadiyah Sumatera Utara, Medan. t.t.

Aziz, Moh. Ali. Ilmu Dakwah Edisi Revisi. Jakarta: Prenadamedia Group, 2016.

bangkatimes.com. "Hadir di Pangkalpinang, Ustadz H M Syauqi MZ Obati Kerinduan Umat Kepada KH Zainuddin M.Z.." Bangkatimes.com, 23 Juli 2017. http://bangkatimes.com/23/07/2017/hadir-di-pangkalpinang-ustadz-h-m-syauqimz-obati-kerinduan-umat-kepada-kh-zainuddin-mz/.

Bangmu2 Official. Ceramah KH Zainuddin M.Z. Iucu,, "Isro Miroj". MP4 Video. Dongkal, Serpong, Tanggerang Selatan, 2018. https://www.youtube.com/watch?v=CULilzpoxN8\&t=15s.

Ceramah K.H. Zainuddin M.Z. Waduh Ibu-Ibu Ketawa Terpingkal-pingkal Ngakak-Live K.H. Zainuddin M.Z.. MP4 Video. Dongkal, Serpong, Tanggerang Selatan, 2018. https://www.youtube.com/watch?v=mftrf40MoOI\&t=21s.

Ceramah lucu K.H. Zainuddin M.Z.. MP4 Video, t.t.

Creswell, John W. Research Design Pendekatan Kualitatif, Kuantitatif, dan Mixed. Disunting oleh Saifuddin Zuhri Qudsy. Diterjemahkan oleh Achmad Fawaid. Yogyakarta: Pustaka Pelajar, 2014.

Jiarianto, Wisnu Ardana A. "Kajian Diksi dan Gaya Bahasa Ceramah Agama K.H. Abdullah Gymnastiar." Skripsi, Universitas Airlangga Surabaya, 2016.

Kementerian pendidikan dan kebudayaan. "KBBI Daring," t.t. https://kbbi.kemdikbud.go.id/entri/sekarat.

Keraf, Gorys. Diksi dan gaya bahasa: komposisi lanjutan I. Jakarta, Indonesia: Gramedia, 2009.

KH ZAINUDDIN M.Z. - MEMORIES, CERAMAH TERAKHIR SEMINGGU SEBELUM MENINGGAL KH ZAINUDDIN M.Z. PART 1. MP4 Video. Dongkal, Serpong, Tanggerang Selatan, 2018. https://www.youtube.com/watch?v=Nw1hadoo6Ac.

Matanasi, Petrik. "Zainuddin M.Z.: Dai Sejuta Umat, Politikus Sejuta Massa," tirto.id, 5 Juli 2011. https://tirto.id/zainuddin-mz-dai-sejuta-umat-politikus-sejuta-massa-cCKz.

Niamulloh, Mohammad. "Diksi Pesan Dakwah Kiai Syafi'ul Anam dalam Acara Silaturrahim Tanggal 17 Juni 2018 di Desa Penidon-Plumpang-Tuban." Skripsi, UIN sunan Ampel Surabaya, 2018. 
Ningrum, Desi Arditia. "Cerita KH Zainuddin M.Z. dua minggu sebelum wafat." 28 Mei 2017. https://www.merdeka.com/peristiwa/cerita-kh-zainuddin-mz-dua-minggusebelum-wafat-ramadan-2017.html

Rakhmat, Jalaluddin. Retorika Modern Pendekatan Praktis. Bandung: Remaja Rosdakarya, t.t.

Sucipto, Maya Agustina. Ensiklopedia Bahasa dan Sastra Indonesia Gaya Bahasa. Klaten: Intan Pariwara, 2018

2018

Gaya bahasa Pengetahuan dan Penerapan. Klaten: Intan Pariwara,

Tarigan, Henry Guntur. Pengajaran Gaya Bahasa. Bandung: Penerbit Angkasa, 1985.

Zamzamy, Naila. "Teknik Pesiapan Dakwah Siti Maisaroh". Skripsi, Universitas Islam Negeri Sunan Ampel Surabaya, 2018. 
Gaya Bahasa K.H. Zainuddin M.Z. dalam Ceramah Isra Mikraj di Tengerang Selatan 